\title{
Herpes simplex mastitis: Case report and review of the literature
}

\author{
Holly Brown mD, PAul KNEAFSEy mB, AMAR KUREISHI MD
}

\begin{abstract}
H BROWN, P KNEAFSEY, A KUREISHI. Herpes simplex mastitis: Case report and review of the literature. Can J Infect Dis 1996;7(3):209-212. The most common sites of herpes simplex virus (HSV) infection are around the oral cavity and the genitalia. However, HSV can infect any skin or mucous membrane surface. One uncommon site of HSV infection is the breast. Reports of herpetic breast infections are predominantly cases of transmission from a systemically HSVinfected neonate to the mother during breast-feeding. A review of the literature identified only six reports suggesting HSV breast lesions acquired by means other than through an infected infant. Of these, only one report suggests HSV transmission to the breast from a male sexual partner. A second case of clinically unsuspected symptomatic herpes mastitis presumably acquired from sexual contact in a 46-year-old woman is presented. Herpes simplex type 1 was isolated by using polymerase chain reaction and restriction fragment length polymerization techniques. The purpose of this report is to alert physicians to HSV mastitis.
\end{abstract}

Key Words: Breast infection, Herpes simplex virus, Polymerase chain reaction, Restriction fragment length polymerization

\begin{abstract}
Mastite herpétique : rapport de cas et survol de la littérature
RÉSUMÉ : Les sièges les plus fréquents de l'infection à herpes simplex sont le pourtour de la bouche et les organes génitaux. Or, le HSV peut infecter toute surface muqueuse ou cutanée. L'un des sièges moins fréquents de l'infection par HSV est le sein. Les rapports d'infections mammaires herpétiques concernent surtout des cas de contamination de la mère par un nouveau-né souffrant d'une infection au HSV systémique lors de l'allaitement. Un survol de la littérature n'a permis d'identifier que six rapports suggérant des lésions mammaires herpétiques acquises autrement que par le contact d'un nourrisson infecté. Parmi ces cas, un seul suggère la transmission du HSV au sein par un partenaire sexuel masculin. Un deuxième cas de mastite herpétique symptomatique non soupçonnée cliniquement et présumément acquise lors d'un contact sexuel est présenté ici chez une femme de 46 ans. L'herpes simplex de type I a été isolé à l'aide d'une technique d'amplification génique et de fragments de restriction. Le but de ce rapport est d'alerter les médecins au sujet de la mastite herpétique.
\end{abstract}

$\mathrm{T}$ he most common sites of herpes simplex virus (HSV) infection are around the oral cavity and the genitalia. However, HSV can infect any skin or mucous membrane surface, in addition to the eyes, central nervous system and viscera. HSV skin infections are preceded by a break in the integrity of the skin, as occurs in the well documented cases of herpetic whitlow and herpes gladiatorum. Transmission through intact skin probably does not occur (1-3). One uncommon site of HSV infection of the skin is the breast. Reports of herpetic breast infections are predominately cases of transmission from a systemically HSV-infected neonate to the mother during breastfeeding. A comprehensive review of the English literature identified only six reports suggesting HSV breast lesions acquired by means other than through an infected infant. Three

Department of Histopathology, and Department of Microbiology and Infectious Disease, Foothills Hospital and the University of Calgary, Calgary, Alberta

Corrspondence and reprints: Dr Holly Brown, Department of Pathology, Foothills Hospital, 140329 Street NW, Calgary, Alberta T2N 2T9.

Telephone 403-670-5723, fax 403 670-4748, e-mail habrown@acs.ucalgary.ca

Received for publication October 3, 1995. Accepted December 20, 1995 


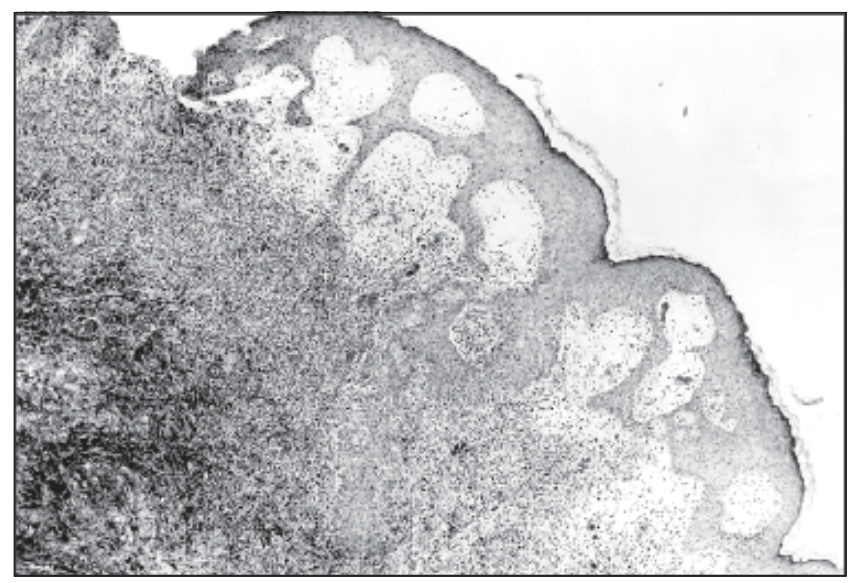

Figure 1) Hematoxylin and eosin stained section of the patient's breast biopsy showing ballooning and reticular degeneration of the epidermis and a mixed inflammatory cell infiltrate

of these reports do not specify how the breast became infected with HSV, but the virus was either culture-proven or infected a previously healthy infant during breast-feeding (4-6). In one case, the virus was culture-proven and was presumably acquired by autoinoculation from an oral lesion (5). Only one report suggests transmission of HSV to the breast from a male sexual partner with recurrent oral HSV lesions (7). We present a second case of symptomatic herpetic mastitis acquired possibly from sexual contact in a 46-year-old woman.

\section{CASE PRESENTATION}

A 46-year-old female presented to Calgary's Foothills Hospital Emergency Department with pain, erythema and swelling in her left breast. Four days earlier, she had experienced pruritus and noticed a small nonspecific white lesion on the medial aspect of her left areola. She attempted to clean the area with a cotton swab, but progressive erythema and pain developed in this region over the next two days. She saw her family physician, who prescribed oral ciprofloxacin $500 \mathrm{mg}$ bid and topical bacitracin. She failed to improve over the next $48 \mathrm{~h}$ and presented to the emergency department, at which time she was seen by the infectious diseases service.

Further history revealed the patient to be in otherwise good health. She denied a history of recent breast trauma or previous breast lesions. She had not breast-fed any of her three children. She had had a normal routine mammogram and pelvic examination the year before. She was admitted to hospital 13 years previously for depression resulting from physical and sexual abuse by her former husband.

Emergency room examination revealed a $10 \mathrm{~cm}$ area of indurated erythema with a central $2.5 \mathrm{~cm}$ eschar on the medical aspect of the left breast that extended to the medial margin of the areola, but spared the nipple. There was no discharge, vesicles, fluctuance, fever or axillary adenopathy. Although the patient denied it, the appearance of the lesion strongly created suspicion that it had been inflicted by a bite. Bacterial mastitis was diagnosed, and she was treated with cefazolin

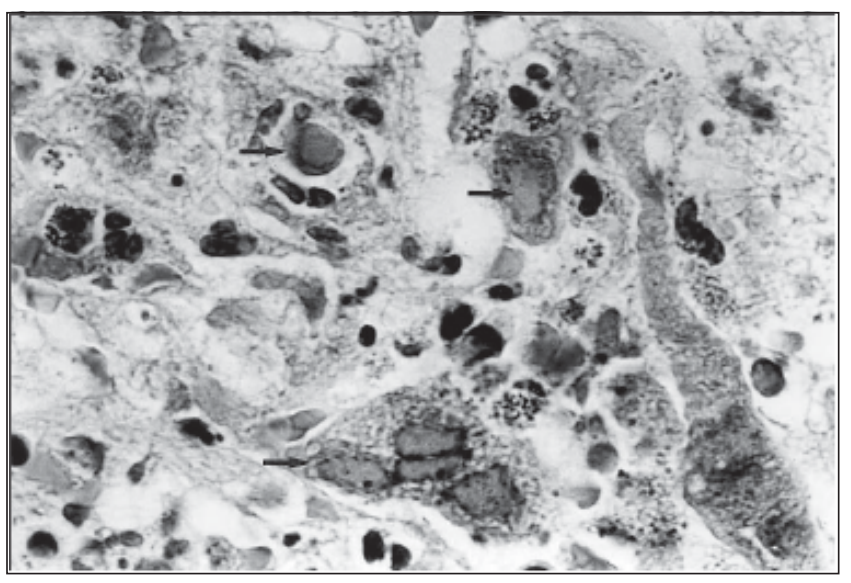

Figure 2) Hematoxylin and eosin stained section. Multinucleated giant cells and keratinocytes with intranuclear inclusions (arrows) diagnostic of herpes infection are present in an inflammatory background

$2 \mathrm{~g}$ intravenously every $8 \mathrm{~h}$ and metronidazole $500 \mathrm{mg}$ intravenously every $8 \mathrm{~h}$ as an out-patient (two doses received).

She returned to the emergency room the following day feeling unwell and unable to cope, although clinically the breast had reduced erythema and swelling. She was admitted to hospital and a surgeon was consulted because of a suspected breast abscess. An incision and drainage were carried out the following day under general anesthetic. During surgery no abscess was discovered, but bacterial cultures and a breast tissue biopsy were obtained for histopathological examination.

\section{LABORATORY INVESTIGATIONS}

Complete blood count was normal and bacterial cultures were negative. However, the breast biopsy was diagnostic. By light microscopy, the epidermis was focally ulcerated and necrotic with adjacent ballooning and reticular degeneration of the epidermis forming vesicles. The epidermal-dermal interface was diffusely infiltrated by a mixed inflammatory cell infiltrate (Figure 1). Intermixed with the inflammation were mononuclear and multinucleated giant cell keratinocytes with Cowdry type A and B intranuclear inclusions; these inclusions are specific to herpes varicella/zoster and simplex virus infection $(8,9)$ (Figure 2). A diagnosis of herpes mastitis was made and subsequently confirmed by immunohistochemistry.

Because viral cultures were not obtained during the patient's admission, breast tissue obtained from the paraffinembedded tissue was examined for HSV DNA by polymerase chain reaction (PCR) and restriction fragment length polymerization using methodology similar to that published previously $(10,11)$.

Sections of $200 \mu \mathrm{m}$ thick tissue were deparaffinized in xylene and absolute alcohol. Following deparaffinization, sections were incubated overnight in $10 \mathrm{~mL}$ of lysis buffer $(50$ mM Tris-HCl, $\mathrm{pH} \mathrm{8.0;} 20$ mM sodium EDTA, $\mathrm{pH} \mathrm{8.0;} \mathrm{and} \mathrm{1 \%} \mathrm{so-}$ dium dodecyl sulphate) and $100 \mu \mathrm{g} / \mathrm{mL}$ of proteinase K. Following protein digestion, DNA was extracted using a phenol-chloroform method and precipitated with sodium chloride-isopropanol by conventional methods. 


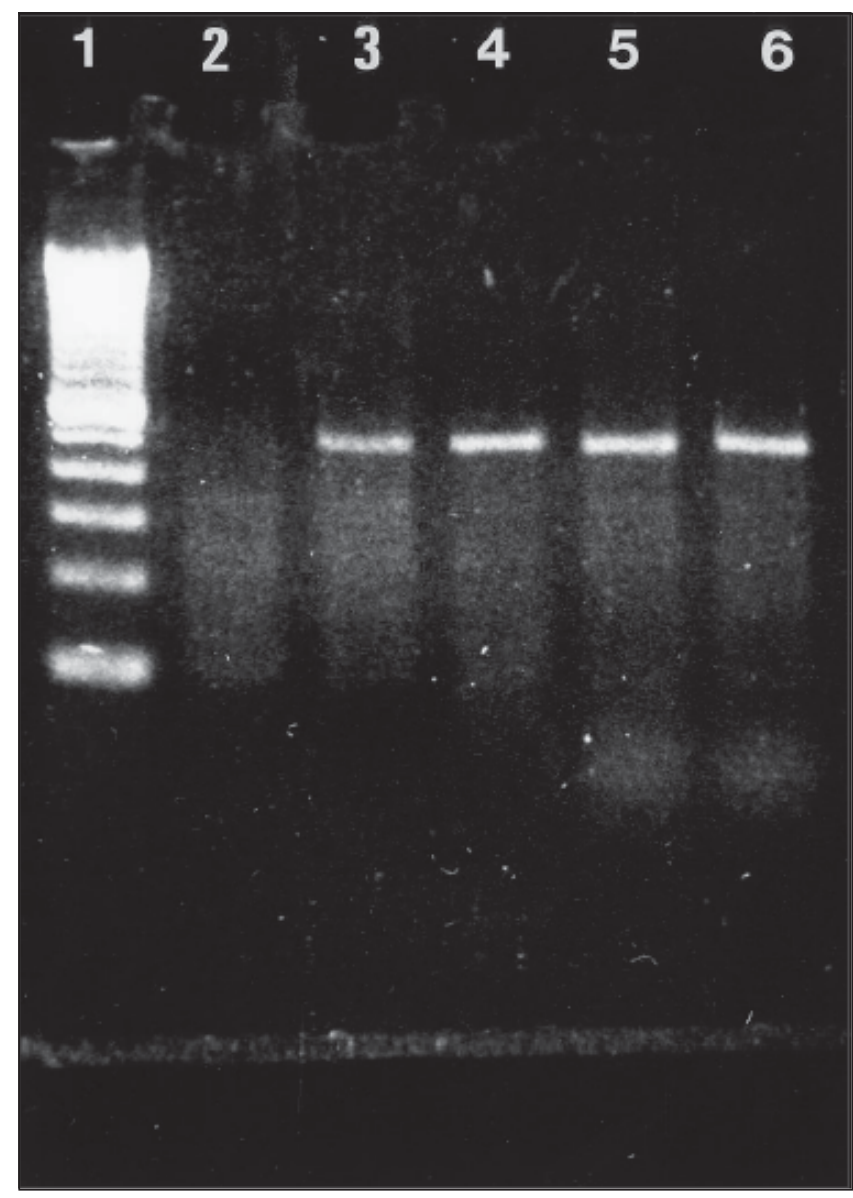

Figure 3) Polymerase chain reaction (PCR) products of herpes simplex virus (HSV) types 1 and 2 gene after gel electrophoresis and ethidium bromide staining. HSV PCR amplification using HSV types 1 and 2 specific primers yielded a 474 base pair product in both the test sample lanes and the control lanes. Lane 1 is a molecular weight control, lane 2 the negative control ( $75 \mathrm{ng}$ of salmon sperm genomic DNA), lanes 3 and 4 control HSV types 1 and 2, respectively, and lanes 5 and 6 the patient's biopsy sample. This pattern confirms the presence of HSV infection in the breast biopsy

Type specific primers to known sequences of HSV DNA (HSV 1 primer sequence: GenBank ACCESSION X14112 D00317; HSV 2 primer sequence: GenBank ACCESSION M16321) were obtained for PCR amplification. HSV primer 1 and primer 2 sequences consisting of (5'-GTACGGCCCCGAGTTCGTGA-3') and (5'-TAGATGGTGCGGGTGATGTT-3'), respectively, were produced and each primer yielded a 474 base pair product. (Beta-globin and HSV type specific primer sequences were produced in the DNA Synthesis Lab, University of Calgary).

Beta-globin control and target HSV sequences were amplified in two separate cycles in a $50 \mu \mathrm{L}$ reaction mixture containing $0.05 \mu \mathrm{g}$ of purified DNA sample, $10 \mathrm{mM}$ of Tris- $\mathrm{HCl}(\mathrm{pH}$ $\left.8.3,25^{\circ} \mathrm{C}\right), 50 \mathrm{mM}$ magnesium chloride, $80 \mu \mathrm{M}$ each of deoxynucleoside triphosphates, $100 \mathrm{ng}$ of salmon sperm DNA, 1.25 units of Taq DNA polymerase (Perkin-Elmer Cetus, Connecticut), and 0.1 to $0.4 \mu \mathrm{M}$ ( 5 to $20 \mathrm{pmol}$ ) of each primer sequence. The mixture was denatured initially for 5 mins at $95^{\circ} \mathrm{C}$, followed by 35 cycles of amplification using a TR-96

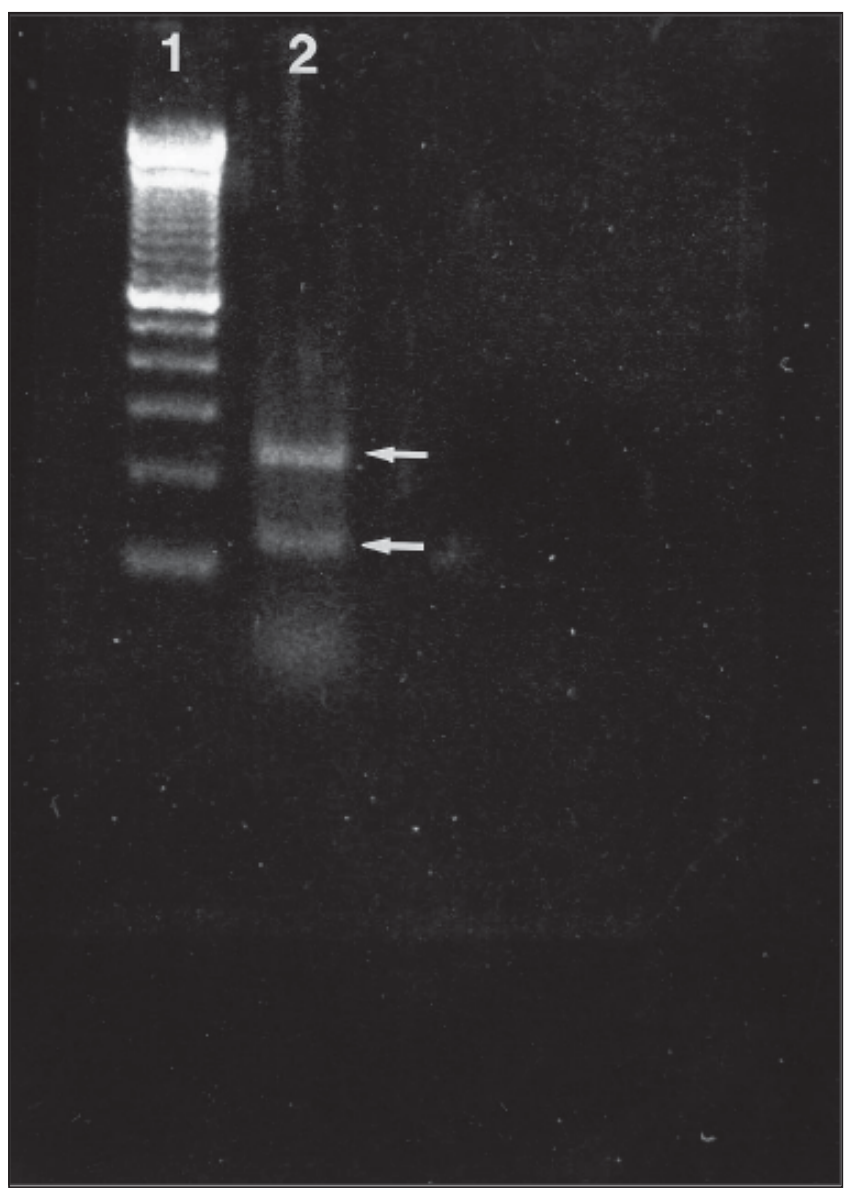

Figure 4) Restriction enzyme analysis following digestion of polymerase chain reaction products using Mbo 1 . Lane 1 is the molecular weight control. Lane 2 shows the presence of two base pair products of respective sizes 228 and 123 (arrows). This pattern is characteristic of herpes simplex virus type 1

thermal reactor (Tyler Research Instruments Company). Each cycle consisted of denaturation at $95^{\circ} \mathrm{C}$ for $30 \mathrm{~s}$, annealing at $56^{\circ} \mathrm{C}$ for 2 mins and extension at $72^{\circ} \mathrm{C}$ for $1 \mathrm{~min}$, with a final extension at $72^{\circ} \mathrm{C}$ for 6 mins.

Following the last cycle of amplification, $8 \mu \mathrm{L}$ of product was analyzed by Southern blot. By using the specific alkaline phosphatase-conjugated oligonucleotide (HSV PR-307 [5'-CGA CATCCCCGCCTACTACGCCGCCG-3']) detection probe, the product was run by agarose gel electrophoresis and stained with ethidium bromide. A 474 base pair amplification product was obtained and confirmed the presence of HSV in the breast biopsy (Figure 3).

Viral typing was carried out by restriction enzyme analysis of the PCR products. The enzyme Mbo I (Gibco BRL) was used to digest the PCR products, and two DNA fragments of 228 and 123 base pairs were identified by gel electrophoresis, which is diagnostic of HSV type 1 (Figure 4).

\section{POSTOPERATIVE COURSE}

The patient was discharged from hospital three days after surgery. Because the diagnosis was not suspected at the time of presentation, viral cultures and serology were not obtained 
and acyclovir was not offered. Instead, antibacterial agents were continued for the incorrect diagnosis of bacterial mastitis and the mastitis resolved spontaneously over two weeks.

The patient was subsequently seen for follow-up six months later and there was no recurrence or new lesions. Additional history was obtained and she denied ever having had oral or genital HSV lesions. She was sexually active with a single partner for five years; he had no noticeable oral or genital HSV lesions. However, her former husband, who had been physically abusive, had had oral HSV lesions.

\section{DISCUSSION}

Infection of the breast by HSV is uncommon. Only $2 \%$ of all extragenital herpetic lesions have involved the breast (12). Furthermore, development of breast lesions as the first and sole manifestation of clinically apparent HSV infection without oral or genital herpes is uncommon (13). However, oral and genital HSV infections can be asymptomatic. There is little information in the literature regarding transmission of HSV to the breast except in cases associated with neonatal breast-feeding, and because further inquiry failed to reveal the source of the herpes virus in this patient we are left to speculate as to the means of transmission.

It seems reasonable to consider three possible means of transmission in this case. One possibility is that the virus was transmitted to the breast through autoinoculation from an asymptomatic oral or genital lesion. Autoinoculation to other body sites such as face, fingers, eyes and genitalia without clinical manifestations of a primary lesion have been reported $(12,13)$, but there is only one case in the literature of presumed autoinoculation from known oral HSV lesion to the breast (6). Second, the patient may have acquired a subclinical infection of the breast 13 years previously from her first husband, who was known to suffer from cold sores, and the recent breast lesion was a reactivation after a long latency. Primary infection with HSV type 1 may be subclinical $(2,3,8,13)$; however, primary dermal lesions are more frequently symptomatic $(2,13)$ and generally associated with more severe symptoms (constitutional symptoms, local adenopathy and more extensive skin lesions) than with recurrences (12). Unfortunately, because the diagnosis of herpes mastitis was not suspected, serology was not obtained from the patient at the time of ad-

\section{REFERENCES}

1. Sealander JY, Kerr CP. Herpes simplex of the nipple: infant to mother transmission. Am Fam Physician 1989;39:111-3.

2. Selling B, Kibrick S. An outbreak of herpes simplex among wrestlers. N Engl J Med 1964;270:979-82.

3. Haynes RE. The spectrum of herpes simplex virus infections in children. South Med J 1976;69:1069-78.

4. Kalman CM, Laskin OL. Herpes zoster and zosteriform herpes simplex virus infections in immunocompetent adults. Am J Med 1986;81:775-8.

5. Kobayashi TK, Okamoto H, Yakushiji M. Cytologic detection of herpes simplex virus DNA in nipple discharge by in situ hybridization. Diagn Cytopathol 1993;9:296-9.

6. Whiteley RJ, Nahmias AJ, Visintine AM, Fleming CL, Alford CA. The natural history of herpes simplex virus infection of mother and newborn. Pediatrics 1980;66:489-94.

7. Sullivan-Bolyai JZ, Fife KH, Jacobs RF, Miller X, Corey L. Disseminated neonatal herpes simplex virus type 1 from a mission to hospital to help distinguish this as a primary or recurrent infection. Third, this lesion may have been a primary infection of the breast from recent sexual contact with an asymptomatic HSV carrier. Infected asymptomatic individuals can carry the virus in saliva and transmit the virus through close personal contact $(2,13,14)$. This mode of transmission is well documented in cases of medical and dental personnel becoming infected with HSV after contact with the oral cavity of an asymptomatic carrier.

In the present case, the latter means of transmission is considered most likely. Recent sexual transmission from a partner with oral HSV infection is considered most likely because the lesion clinically looked like a bite, the patient had no personal history of previous HSV infection, and she had constitutional symptoms and an extensive lesion more frequently associated with primary infection than with recurrence.

Regardless of the exact mechanism by which our patient acquired the infection, the purpose of this report is to review the various modes of HSV transmission to the breast and to consider the clinical significance of establishing the correct diagnosis.

First, HSV infection should be considered in any case of ulcerating mastitis unresponsive to antibiotics. Second, it is important to distinguish between herpes mastitis and a bacterial abscess because herpetic lesions heal spontaneously in seven to 10 days without scarring, while an abscess requires surgical drainage with residual scarring. Third, there have been two cases misdiagnosed as varicella-zoster mastitis, which were later proven by culture to be HSV infections (4). This distinction is important in counselling the patient, because zoster lesions may become confluent and hemorrhagic, heal slowly with scarring, and can be associated with residual neuralgia (9).

Finally, the differential diagnosis of all maternal breast lesions should include HSV because of the potential for transmission to an otherwise healthy neonate and the potentially disastrous implications of disseminated herpes infection in the neonate. Two of the six cases of HSV breast infections reported in the literature were acquired by nonspecified means and resulted in previously healthy infants becoming fatally infected after breast feeding $(6,7)$.

maternal breast lesion. Pediatrics 1983;71:455-7.

8. Lever WF, Schaumburg-Lever G. Histopathology of the Skin, 7 th edn. Philadelphia: JB Lippincott Co, 1990:399-406.

9. Hood AF. Viral diseases. In: Farmer ER, Hood AF, eds. Pathology of the Skin. Englewood Cliffs: Prentice Hall,1990:309-10.

10. Saiki RK, Scharf S, Faloona F, et al. Enzymatic amplification of betaglobin genomic sequences and restriction site analysis for diagnosis of sickle cell anemia. Science 1985;230:1350-4.

11. Larsen ET, Duggan MA, Inoue M. Absense of HPV DNA in oropharyngeal spindle cell squamous carcinoma. Am J Clin Pathol 1994;101:514-8.

12. Corey L, Adams HG, Brown ZA, Holmes KK. Genital herpes simplex virus infections: clinical manifestations, course, and complications. Ann Intern Med 1983;98:958-72.

13. Nahmias AJ, Roizman B. Infection with herpes simplex viruses 1 and 2. N Engl J Med 1973;289:719-25.

14. Green LH, Levin MP. An unusual primary infection with herpes simplex virus: a case report. J Periodontol 1971;42:170-2. 


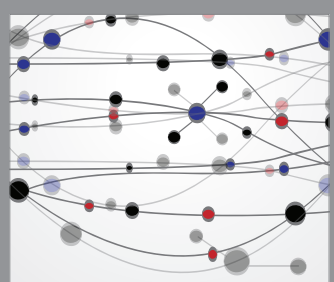

The Scientific World Journal
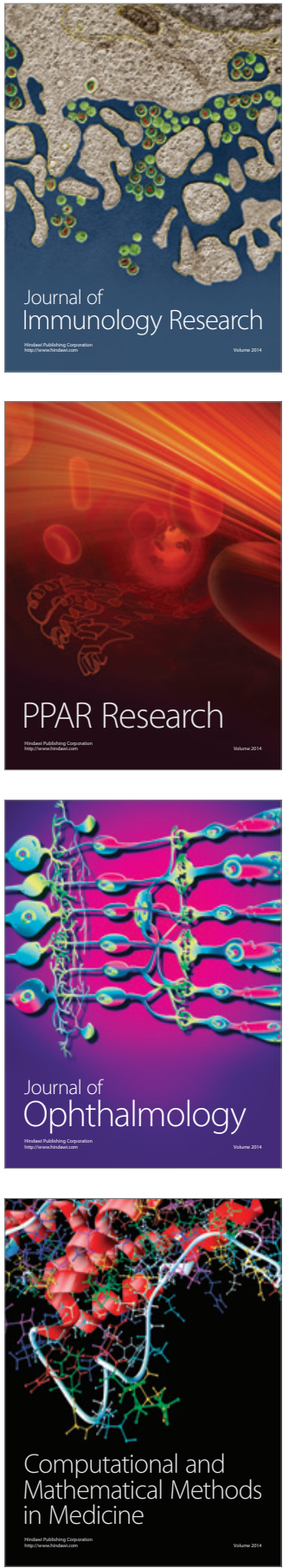

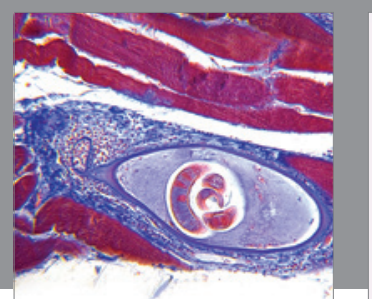

Gastroenterology Research and Practice

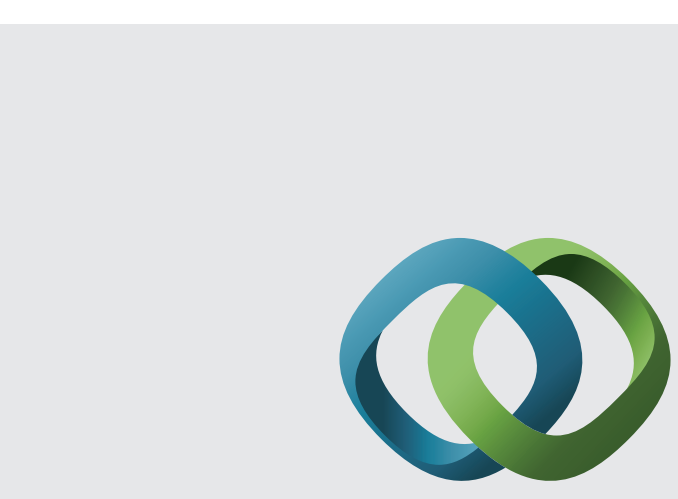

\section{Hindawi}

Submit your manuscripts at

http://www.hindawi.com
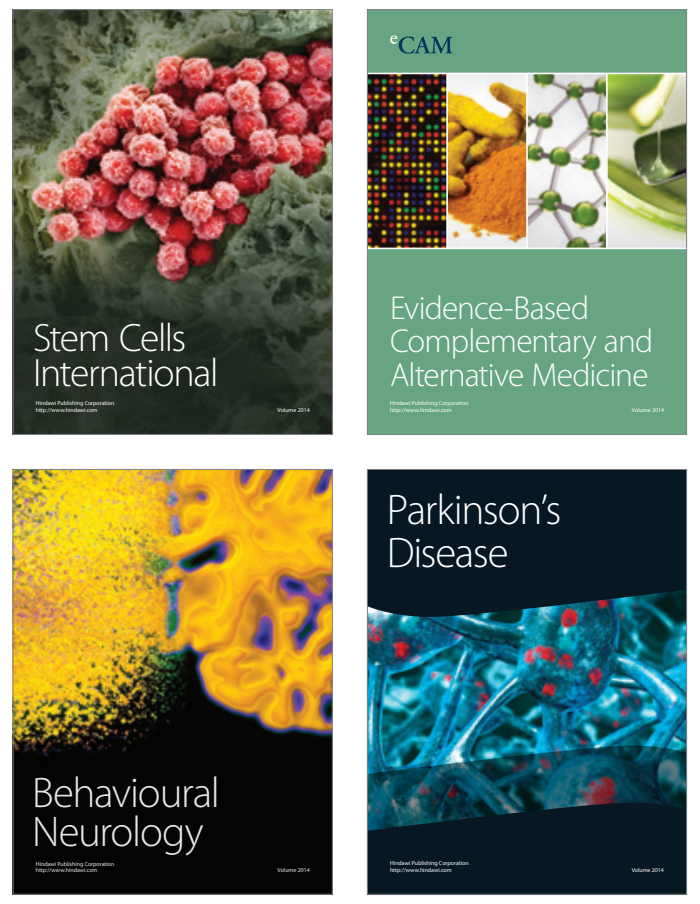
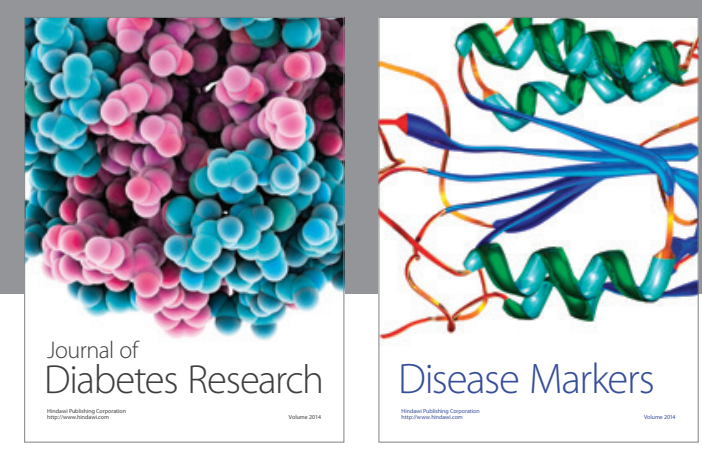

Disease Markers
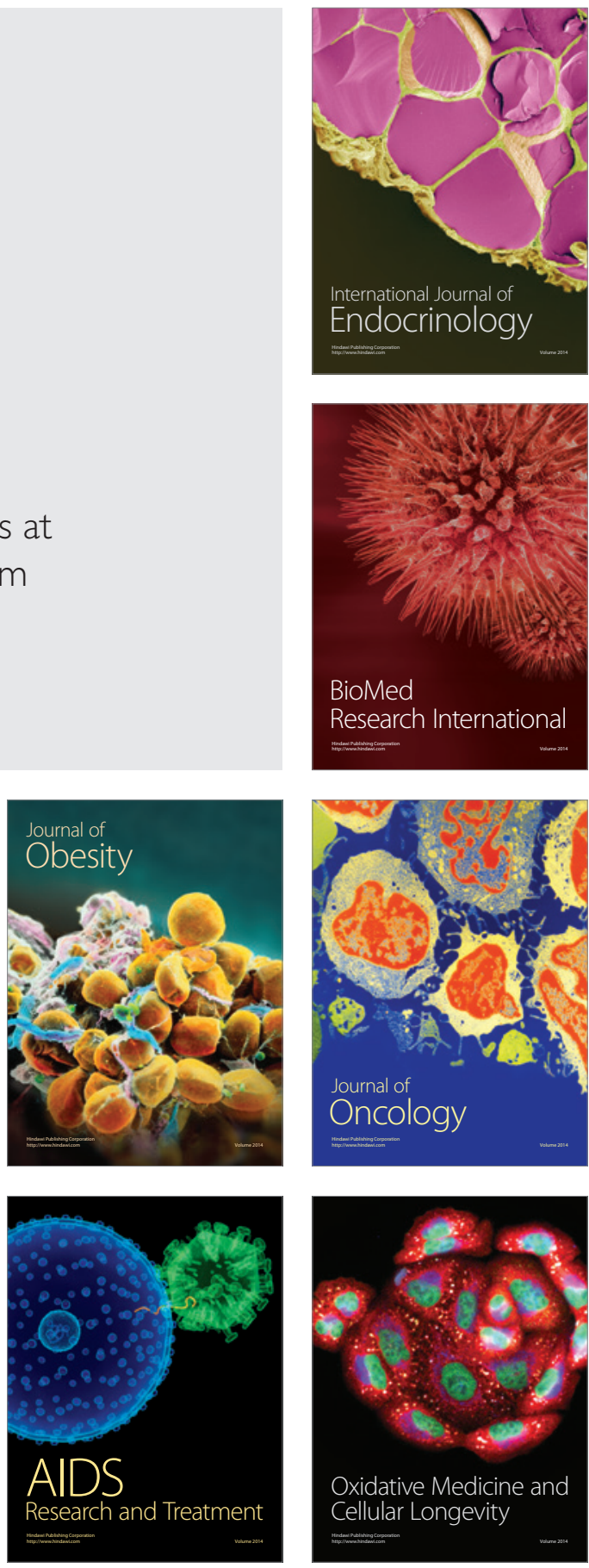